\title{
Introduction to Children's Constitutional Rights in the Nordic Countries
}

\author{
Anna Nylund
}

Thirty years ago, the adoption of the United Nations Convention of the Rights of the Child (CRC) reaffirmed children as rights-holders and the existence of children's rights as a particular set of human rights. The CRC represents a comprehensive child law perspective and can, as such, serve as a model for countries aspiring towards a genuine child-rights-approach in their national constitutional law. However, the CRC does not entail an obligation to provide constitutional protection of children's rights. It mandates only appropriate legislative and administrative protection supplemented by other measures implementing the rights enshrined in it. $^{1}$

Although protection of children's rights in an international convention is essential, the question arises whether and how enshrining these rights in national Constitutions enhances the level of protection and opportunities to vindication of the rights. Constitutional protection could render visibility to children as rights-holders and could avail stronger arguments in favour of treating children as 'fully-fledged human beings'. ${ }^{2}$ Additionally, it could propel implementation and enforcement of those rights. ${ }^{3}$ In challenging

1 Committee on the Rights of the Child, General comment no. 5, general measure of implementation of the Convention on the Rights of the Child (arts. 4, 42 and 44, para. 6) (27 November 2003) $\mathrm{CRC} / \mathrm{GC} / 2003 / 527$ para 21 appears to support this view.

2 Didier Reynaert and others, 'Introduction: A critical approach to children's rights' in Wouter Vandenhole and others (eds), Routledge International Handbook of Children's Rights Studies (Routledge 2015) 3 .

3 See Conor O'Mahony, 'Constitutional Protection of Children's Rights: Visibility, Agency and Enforceability', (2019) Human Rights Law Review (in press), with further references for a closer discussion of the topic. See also eg Aoife Nolan, Children's Socio-Economic Rights, Democracy and the Courts (Hart Publishing 2011); Michael Freeman, 'Why it Remains Important to Take Children's Rights Seriously' (2007) 15 Int'l J of Children's Rights $5^{-23}$ doi:10.1163/ 0927556o7X181711; John Tobin, 'Increasingly Seen and Heard: The Constitutional Recognition of Children's Rights' (2005) 21 South African Journal on Human Rights 86-126.

(C) ANNA NYLUND, 2020 | DOI:10.1163/9789004382817_002

This is an open access chapter distributed under the terms of the CC-BY-NC 4.O Licensegna Ny lund - 9789004382817 
the adult-centricity of the legal system, and the prevalent ideas of autonomy, children's rights face multiple impediments on numerous levels. Effective implementation necessitates shifts in attitudes, practices and regulation through various mechanisms such as training and providing sufficient resources. ${ }^{4}$ Enshrining rights in the Constitution mandates change. In the words of Julia Sloth-Nielsen and Helen Kruuse, constitutional protection signifies that children's rights 'cannot be overlooked, rendered perfunctory or written out of the script'. ${ }^{5}$ The combined effect of national and international protection, the consolidation between national constitutional law and international instruments will plausibly be superior to using one method only. ${ }^{6}$

Whether or not children are explicitly mentioned in the Constitution is probably an insufficient indicator of the extent to which children's rights are rendered efficient. A specific provision on children's rights in the national Constitution could have mere symbolic value. Conversely, a Constitution that remains silent on the issue does not necessarily entail weak protection of children's rights in practice. A recent study by the Venice Commission uncovered significant variation in the extent to which children's rights are explicitly set down in Constitutions across Europe. ${ }^{7}$ In it, children's rights were analysed through a spectrum of three indicators: visibility, agency and enforcement. ${ }^{8}$ The Venice Commission study found striking variations among protection of children's constitutional rights across Europe: some countries considered 'child-friendly' scored surprisingly low on all parameters. Neighbouring countries with similar cultures, laws and societies received disparate scores. Due to the scope and methods chosen, the study was unable to measure the

4 Wouter Vandenhole, 'Children's Rights from a Legal Perspective: Children's Rights Law' in Wouter Vandenhole and others (eds) Routledge International Handbook of Children's Rights Studies (Routledge 2015) 38-39.

5 Julia Sloth-Nielsen and Helen Kruuse, 'A Maturing Manifesto: The Constitutionalisation of Children's Rights in South African Jurisprudence 2007-2012' (2013) 21 Int'l J of Children's Rights 646, 677 .

6 Committee on the Rights of the Child, General comment no. 5 (n 1 ) paras 18-23.

7 European Commission for Democracy through Law (Venice Commission), Report on the Protection of Children's Rights: International Standards and Domestic Constitutions (3 April 2014) Opinion no 713 / 2013. CDL-AD (2014) oo5.

8 Later, O'Mahony has developed and refined the methodology, see O'Mahony (n 3 ) and Trude Haugli and Anna Nylund, 'Children's constitutional rights in the Nordic countries: Do constitutional rights matter?' in Trude Haugli and others (eds), Children's Constitutional Rights in the Nordic Countries (Brill 2019). 
interlinkages between constitutional law and children's rights as implemented in legal regulation and practice.

Therefore, the question arises whether differences in constitutional law influence implementation and enforcement of children's rights. Is constitutional protection reflected in legal regulation, practices and thinking in various domains or does constitutional protection offer merely symbolic recognition of children's rights? Does the level of constitutional protection of children's rights reflect primarily recognition of children as autonomous rights' holders and the attitude towards children or could other factors offer a more convincing explanation? Do constitutional rights 'trickle down' to statutory law, case law and other sources of law, and to legal practices and, if so, how? Is level of protection of children's rights primarily contingent on how and to which extent children's rights are manifested in 'ordinary' law rather than constitutional law? And if so, does constitutional protection provide additional benefits? A more detailed study could perhaps reveal that some provisions primarily reiterate existing legal principles whereas other provision were enacted to provide improved tools for advocacy of children's rights.

This volume attempts to explore the interconnections between children's constitutional rights and the implementation and enforcement of children's rights by studying the five Nordic countries: Denmark, Finland, Iceland, Norway and Sweden. The primary aim is to bring new insight on children's constitutional rights and their impact on children's legal rights in practice by applying a critical child law perspective. While the Nordic countries have similar societies, cultures and legal systems, the constitutional protection of children's rights ranges from a single provision on educational rights, to a dedicated provision for children in form of a shorthand version of the CRC. These countries offer an interesting object to examine the interrelationship of the wording of the Constitution and implementation of rights. This volume examines which children's rights are included - directly or indirectly - in the Nordic Constitutions and how these rights are interpreted and enforced in national law. The aim is to analyse factors influencing these interpretations.

Three central rights have been selected for further scrutiny: the best interests of the child, the right to participation and the right to family life. The study of these rights enables a closer investigation of central rights in addition to more general discussions of constitutional rights.

Before proceeding to a more detailed account of our study, a short introduction to the Nordic countries in general and constitutional law and children's rights, in particular, is given in the next two parts. 


\subsection{A Brief Introduction to the Nordic Countries}

The Nordic - or Scandinavian - countries ${ }^{9}$ Denmark, Finland, Iceland, Norway and Sweden have close cultural, economic, geographic, historical, linguistic, legal and social ties. Their shared legal history can be traced back to the high middle ages. Between the Reformation in the early 15 oos and the Napoleonic wars in the early 180os, there were two Nordic countries: Denmark and Sweden. Iceland and Norway were under Danish rule, and Finland under Swedish rule. In the aftermath of the Napoleonic wars, Finland became part of the Russian empire, but retained most of its Swedish laws. Norway had a union with Sweden, but had its own legal system based on Danish law and developed own legal institutions. Norway gained independence in 1905. Finland declared independence from Russia in 1917. After independence, Finland has maintained its close ties to Sweden: Swedish law has been the main source of influence for legal development. Iceland became independent from Denmark in 1944 but has since retained its legal ties to Denmark. This division between the East-Nordic countries, Finland and Sweden, and the West-Nordic countries, Denmark, Iceland and Norway, is still visible. ${ }^{10}$ Since the 1870 , Nordic legal cooperation has resulted in similar laws and in the Nordic countries serving as a central form of inspiration for legal reforms. ${ }^{11}$

The Nordic countries have similar societies. The economies are organised in a similar manner in what is sometimes called the 'Nordic model'. The societies seek to blend a market economy with generous welfare benefits and universal services offered free-of-charge or for a moderate charge: day care, after-school care, health service and so forth. ${ }^{12}$ Welfare benefits are tax-funded, universal

9 The term Nordic is preferred in this volume, as it is more precise. Geographically, only Norway and Sweden are situated on the Scandinavian Peninsula. Often Denmark is included in Scandinavia, since Danish is a Scandinavian language. So is the Icelandic language, although Iceland is geographically situated between North America and Europe. The Finnish language is not Scandinavian. Indeed, unlike most European languages, it is not even Indo-European. However, the historical, societal, cultural and legal structures in Finland are similar to the other Nordic countries.

10 See also Pia Letto-Vanamo and Ditlev Tamm, 'Nordic Legal Mind' in Pia Letto-Vanamo, Ditlev Tamm and Bent Ole Gram Mortensen (eds), Nordic Law in European Context (Springer 2019).

11 See Pia Letto-Vanamo and Ditlev Tamm, 'Cooperation in the Field of Law' in Johan Strang (ed), Nordic Cooperation: A European Region in Transition (Routledge 2015); LettoVanamo and Tamm (n 10) 14-16. Gøsta Esping-Andersen, The Three Worlds of Welfare Capitalism (Polity Press 1990) 28. 
and awarded to the individual rather than the family. ${ }^{13}$ Each member of society is expected to provide for himself or herself by working, and pension rights are individual, thus both parents work in most families and many children go to day care from the age of $12-18$ months. ${ }^{14}$ Child welfare services are family service oriented, relying on voluntary, preventive and in-home services. The focus is therapeutic and needs-based interventions. ${ }^{15}$ Consequently, even juvenile delinquency is treated primarily as a child protection issue. ${ }^{16}$

The Nordic countries are liberal: co-habitation is ubiquitous, and same-sex partnerships are recognised as a parallel to marriage. Decision making in politics, and in many other organisations, is based on consensus and corporatism. Culturally, people in the Nordic countries value egalitarianism, low hierarchy, directness, collectivism and gender equality. ${ }^{17}$

Legislation is characterised by single statutes rather than comprehensive codes. For instance, parental responsibility and child protection are regulated in separate acts. In Nordic law, the preparatory works of statutes are an important source of law describing the aims of the statute, the leading principles, the relationship to other statutes, and giving general guidelines on interpretation. Although legal thinking and legal concepts derive from Roman-Germanic law, law is less theoretical, and argumentation is pragmatic, practical and informal. The style of legal writing and argumentation in legislation and other legal texts is designed to enable lay persons to comprehend the content. ${ }^{18}$

13 Jørn Henrik Petersen, 'Nordic Model of Welfare States' in Letto-Vanamo, Ditlev Tamm Bent Ole Gram Mortensen (eds), Nordic Law in European Context (Springer 2019); Torben M. Andersen and others, The Nordic Model: Embracing Globalization and Sharing Risks (The Research Institute of the Finnish Economy 2007).

14 For an overview of Nordic family law, see Ingrid Lund-Andersen and Annette Kronborg, 'Marriage and Family Relations' in Letto-Vanamo, Ditlev Tamm and Bent Ole Gram Mortensen (eds), Nordic Law in European Context (Springer 2019); Hrefna Friðriksdóttir, 'Nordic Family Law: New Framework: New Fatherhoods' in Guöný Björk Eydal and Tine Rostgaard (eds), Fatherhood in the Nordic Welfare States: Comparing Care Policies and Practice (Policy Press 2016); Annette Kronborg, 'Family Formation in Scandinavia: A Comparative Study in Family Law' (2016) 12(2) Utrecht Law Review 81-93.

15 Neil Gilbert, Combatting Child Abuse: International Perspectives and Trends (OUP 1997) $232 \mathrm{ff}$.

16 Tarja Pösö, Marit Skivenes and Anne-Dorthe Hestbæk, 'Child Protection Systems Within the Danish, Finnish and Norwegian Welfare States: Time for a Child Centric Approach?' (2014) 17 Eur J of Social Work 475.

17 Gillian Warner-Søderholm, 'But We're Not All Vikings! Intercultural Identity within a Nordic Context' (2012) 29 J of Intercultural Communication.

18 Jaakko Husa, Kimmo Nuotio and Heikki Pihlajamäki, 'Nordic Law - Between Tradition and Dynamism' in Jaakko Husa, Kimmo Nuotio and Heikki Pihlajamäki (eds), Nordic Law: Between Tradition and Dynamism (Intersentia 2007). 
The Nordic countries have simple three-tiered court systems with little specialisation. The systems consist of District Courts, Courts of Appeal and the Supreme Court. Until 2018, Iceland was an exception with a two-tiered system. Finland and Sweden have administrative courts in addition to general courts. The Finnish administrative court system is two-tiered, the Swedish system is three-tiered, with Administrative Courts, Administrative Courts of Appeal and the Supreme Administrative Court. The Nordic Supreme Courts are primarily courts of (quasi-)precedent, each hearing approximately 100-140 cases annually. The case law is not formally binding, but lower courts still treat is as if it were binding. ${ }^{19}$ Depending on the country, quasi-courts also have an important role, particularly in child protection law, where the Danish Council of Appeal (Ankestyrelsen) and Norwegian County Social Welfare Boards (Fylkesnemndene for barnevern og sosiale saker) make the decisions on coercive measures.

The relationship to the European Union (EU) divides the Nordic countries: they are the paramount example of multi-speed integration. Denmark has been an EU Member State since 1973 but does not participate fully in home and justice affairs. Finland and Sweden have been Member States since 1995, participating fully in the EU. However, Sweden has not introduced the euro as its currency. Iceland and Norway have been part of the single market since 1994 through the Agreement on the European Economic Area (EEA). ${ }^{20}$ Through the EEA Agreement, EU law regulating the single market is applicable in Iceland and Norway. However, rules on home and justice affairs are not part of the EEA Agreement.

\subsection{Constitutional Law in the Nordic Countries}

The Nordic countries are majoritarian democracies: the doctrine of division of powers is central, but the Parliament is the paramount institution, as it secures popular sovereignty. ${ }^{21}$ In respecting popular sovereignty, courts have

19 Anna Nylund and Jørn Øyrehagen Sunde, 'Courts and Court Proceedings' in Pia LettoVanamo, Ditlev Tamm and Bent Ole Gram Mortensen (eds), Nordic Law in European Context (Springer 2019).

20 Several agreements in the field of family govern inter-Nordic relations. The Nordic countries have also ratified many of the Hague Conventions on family law or are bound by them through EU membership, but there are some exceptions. For an account of the interplay between international, European and Nordic law in the field of family maintenance, see Anna Nylund, 'Family Maintenance and Multi-Speed Integration: A Norwegian Perspective' in Anna Nylund and Magne Strandberg (eds), Civil Procedure and Harmonisation of Law (Intersentia 2019).

21 Jaakko Husa, 'Constitutional Mentality' in Letto-Vanamo, Ditlev Tamm and Bent Ole Gram Mortensen (eds), Nordic Law in European Context (Springer 2019) and Jaakko Husa, Nordic Reflection on Constitutional Law: A Comparative Nordic Study (Peter Lang 2002). 
traditionally been reluctant to perform judicial review, because in doing so they would challenge the 'will' of the people. Rights-based argumentation and debates have been scarce in the Nordic countries, although the importance of constitutional rights has increased in recent years. ${ }^{22}$

When studying the Nordic Constitutions, differences in structure and age are noteworthy. The Norwegian Constitution of 1814 is the oldest. It was inspired by the French and American revolutions, but an extensive bill of rights was enacted only in the 2014 comprehensive reform. Consequently, human rights in the Norwegian Constitution reflects the state-of-the-art of the $2010 s$. The Icelandic Constitution dates from 1944. It has been amended seven times, including a reform in 1995 when the provisions on human rights were modernised and enhanced. The Danish Constitutions dates to 1953 and includes primarily classical freedom rights. The Swedish Constitution consists of four separate acts and has done so for centuries. The four constitutional acts were subject to a comprehensive reform in 1974, and the provisions of human rights have been amended a couple of times since then, most recently in 2010. The Finnish Constitution had, until 2000, the same fragmented structure as the Swedish constitutional acts. A bill of rights was adopted in 1995 to the then constitutional acts, and it was implemented in the 1999 Constitution.

Although the Nordic Constitutions, with the exception of the Danish Constitution, give courts explicitly the right to perform judicial review, courts have been traditionally cautious and exercised their powers with a marked self-restrictedness. In Finland, courts may reject to apply a law only when it is in clear controversy with the Constitution. Until recently, Finnish courts did not have a right to perform judicial review and Swedish courts had the right only when the conflict was obvious (uppenbar). The Icelandic and the Norwegian Supreme Courts are the exception, as they have been more willing to (openly) perform judicial review. ${ }^{23}$ In the Nordic countries, judicial review is

22 Jaakko Husa, 'Nordic Constitutionalism and European Human Rights: Mixing Oil and Water?' (2010) 55 Scandinavian Studies in Law 101, 106; Juha Lavapuro, Tuomas Ojanen and Martin Scheinin, 'Rights-Based Constitutionalism in Finland and the Development of Pluralist Constitutional Review' (2011) 9 Int'l J of Const L 505-531, doi: 10.1093/icon/ moro35; Ran Hirschl, 'The Nordic Counternarrative: Democracy, Human Development, and Judicial Review' (2011) 9 Int'l J of Const L 446, 450 notes that the Nordic countries have been 'agnostic, at best, toward American-style high-voltage constitutionalism, rights talk, and judicial activism'. See also the Nordic J of Human Rights 2009 volume 9 no 2 for articles discussion judicial review in the Nordic countries.

23 Eivind Smith, 'Courts and Parliament: The Norwegian System of Judicial Review of Legislation' in Eivind Smith (ed), The Constitution as an Instrument of Change (SNS Förlag 2003) 171; Ragnhildur Helgadóttir, 'Nonproblematic judicial review: A case study' (2011) 9 Int'l J of Constitutional Law 532. doi: 10.1093/icon/moro55; Husa, 'Constitutional 
decentralised and concrete: any court may find an act of parliament unconstitutional and in doing so the court sets the act aside only in the case at hand, while the act itself remains formally in force. ${ }^{24}$

The Nordic Supreme Courts do not have a political role. Rather, the role of the Supreme Courts has traditionally been to respect the will of the Parliament by avoiding open conflict. The wide range of legal sources available to the courts enable them to evade these conflicts: by interpreting statutory law in the light of the Constitution, the statute is made conform to the Constitution. Judicial self-restraint is mirrored in self-restraint of the legislator, particularly, in the East Nordic countries. In Finland, the Constitutional Law Committee (Perustuslakivaliokunta) of the Parliament reviews the constitutionality of bills through an abstract preview. In Sweden, the Council on Legislation (Lagrådet) has a similar function but has a far weaker position. ${ }^{25}$

The Nordic countries have implemented several international human rights treaties and instruments. The European Convention on Human Rights (ECHR) has been particularly influential since it has a semi- or quasi-constitutional status. Nordic courts use the ECHR in their argumentation, but do so often indirectly by paraphrasing the case law or referring to national scholarship or text books on the Convention, rather than citing case law of the European Court of Human Rights (ECtHR) directly. The Norwegian Supreme Court is the exception, with extensive use of direct citations. It refers to the ECHR significantly more often than its Nordic counterparts do. ${ }^{26}$ Denmark belongs to the other end of the spectrum: there is an outspoken reluctance to transfer

Mentality' (n 21) 52-54 and 56-57; Inger-Johanne Sand, 'Judicial Review in Norway under Recent Conditions of European Law and International Human Rights Law: A Comment' (2009) 27 Nordic Journal of Human Rights 16o-169.

24 Husa, 'Constitutional Mentality' (n 21); Helgadóttir (n 23); Joakim Nergelius, 'Judicial Review in Swedish Law: A Critical Analysis' (2009) 27 Nordic Journal of Human Rights 142; Tuomas Ojanen, 'From Constitutional Periphery Toward the Centre: Transformation of Judicial Review in Finland' (2009) 27 Nordic Journal of Human Rights 194; Sand (n 23); Sten Schaumburg-Müller, 'Parliamentary Precedence in Denmark: A Jurisprudential Assessment' (2009) 27 Nordic Journal of Human Rights 170; Eivind Smith, 'Old and Protected? On the "Supra-Constitutional" Clause in the Constitution of Norway' (2011) 44 Israel LR 369 .

25 Jaakko Husa, 'Guarding the constitutionality of laws in the Nordic countries: A comparative perspective' (2000) 48 AmJCompL 345; Husa, 'Nordic Constitutionalism' (n 22) 101.

26 Anne Lise Kjær, 'European Legal Concepts in Scandinavian Law and Language' (2011) 80 Nordic Journal of Human Rights 321. 
sovereignty to international organisations ensuing from Danish constitutional mentality is present there. ${ }^{27}$

The ECHR combined with the EU and EEA law has shifted the balance of power from the Parliament towards courts. They have spurred a turn towards more overt judicial review. Still, Nordic courts have not fully embraced their new powers and are often hesitant to refer to other human rights conventions than the ECHR. ${ }^{28}$

\section{Children's Rights in Nordic Constitutional Law}

The content and style of each of the Nordic Constitutions indicates the date of enactment or most recent comprehensive reform. Although all human rights are also children's rights, the question remains to which extent the Constitutions have provisions entailing rights specifically aimed at children.

All Nordic Constitutions contain rights that are indirectly aimed at children. The right to education is present in all Nordic Constitutions. ${ }^{29}$ The Danish Constitution, which is primarily restricted to freedom rights, has no other provisions entailing rights specifically or mainly for children.

The Finnish, Icelandic, Norwegian and Swedish Constitutions have a provision banning discrimination. ${ }^{30}$ The Swedish constitutional acts mention

27 Jens Elo Rytter and Marlene Wind, 'In Need of Juristocracy? The Silence of Denmark in the Development of European Legal Norms' (2011) 9 Int'l J of Const L 470, doi: 10.1093/ icon/moro39.

28 Husa, 'Nordic Constitutionalism' (n 22).

29 The Danish Constitutional Act section 76 (Danmarks Riges Grundlov lov nr 169 af o5/ o6/1953, an unofficial English translation available at <https:/www.thedanishparliament.dk/ /media/pdf/publikationer/english/my_constitutional_act_with_explanations .ashx $>$ ) accessed 2 May 2019; Finnish Constitution section 16 (Suomen perustuslaki/ Finlands grundlag 731/1999. an unofficial English translation available at <https:// www.finlex.fi/en/laki/kaannokset/1999/en19990731>) accessed 2 May 2019; Icelandic Constitutional Act art 76 (Stjórnarskrá lýdveldsins Íslands, No 33/1944. An unofficial English translation available at <https:/www.government.is/Publications/Legislation/ Lex/?newsid=89fc6o38-fd28-11 e7-9423-005056bc4d74>) accessed 2 May 2019; the Norwegian Constitution section 109 (Kongerike Norges Grunnlov 17. mai 1814, an unofficial translation available at <https://www.stortinget.no/globalassets/pdf/english/constitutionenglish.pdf>) accessed 2 May 2019; Swedish Instrument of Government, chapter 2 section 18 (Regeringsformen 1974:152, an unofficial translation is available at <https:// www.regeringen.se/4a7991/contentassets/d $72 \mathrm{~cd} 4 \mathrm{od}_{7} \mathrm{c} 4441 \mathrm{dc} 84 \mathrm{f} 93$ ofd $88 \mathrm{efe} 365 /$ theconstitution-of-sweden.pdf $>$ ) accessed 2 May 2019.

30 The Finnish Constitution section 6; the Icelandic Constitution art 65; the Norwegian Constitution section 98; Swedish Instrument of Government chapter 2 section 12. 
primarily ethnic and racial discrimination. The Finnish Constitution has a provision granting equality, and banning discrimination inter alia based on age. The right to family life is protected directly in the Icelandic and Norwegian Constitutions. ${ }^{31}$ The Finnish, Icelandic and Norwegian Constitutions grant citizens the right to basic social security benefits. ${ }^{32}$

The Finnish, Icelandic, Norwegian and Swedish Constitutions explicitly mention children. Of these, the Norwegian Constitution has the most comprehensive regulation. Section 104 is devoted to children's rights and is a shorthand of the rights entailed in CRC. It enshrines provision, protection and participation rights, as well as the best interests-principle. In the Finnish and Icelandic Constitutions, children are referred to in connection with other rights. Section 6 of the Finnish Constitution protects equality. Subsection 3 explicitly recognises children's right to be treated as equals and that children have the right to influence matters pertaining to themselves. The Icelandic Constitution mentions children explicitly in article 76 on social security and education. Subsection 3 obliges the state to provide children protection and care. The Swedish Instrument of Government chapter 1, section 2 is of a declaratory nature expressing the foundational values of the Swedish state. Subsection 5 lists inter alia children's rights, stating that the public has an obligation to protect children's rights. The provision does not give children any rights, however, it does explicitly recognise the existence of children's rights.

The variation in protection of children's rights in constitutional law is significant, at least formally. Other factors may, however, mitigate these differences. The Finnish, Icelandic, Norwegian and Swedish Constitutions include a provision that recognises human rights in general. Except for Iceland, the respective provisions also impose on authorities a duty to guarantee human rights. ${ }^{33}$ These provisions indicate that the listed rights may not be comprehensive. Therefore, the analysis of constitutional rights should not be limited by the wording of the Constitution, but also include semi- or quasi-constitutional rights. Considering that Nordic law recognises a wide range of sources, principles or tenets of law as expressed in preparatory works, court cases and legal doctrine, these may de facto express human rights and even elevate the right contained in them above statutory law. Hence, the wording of the Constitution alone may not be decisive for the level and nature of protection.

31 The Icelandic Constitution art 71 subsection 1; the Norwegian Constitution section 102.

32 The Finnish Constitution art 19; the Icelandic Constitution art 76, Norwegian Constitution section 110.

33 Finnish Constitution section 22; Icelandic Constitution section 64; the Norwegian Constitution section 92; Swedish Instrument of Government chapter 1 section 2. 
This study of children's constitutional rights is limited to the Nordic countries. Studying culturally, legally and societally similar countries with diverging extent of constitutional protection of children's rights enables us to minimise the impact of other factors and hence to attribute differences - at least to some extent - to differences in constitutional law. A further benefit is that most institutions have similar foundations in terms of design, ideas, principles and regulation, which increases comparability. However, limiting the study to related countries constricts transferability of the results. For instance, in countries with a rights-based legal culture and more intensive judicial review, the impact of the wording of the Constitution could be stronger than in the Nordics. Administrative principles and structures as well as cultural issues could also influence implementation and enforcement of children's rights.

This study employs primarily a legal analysis of children's rights from a critical child-law perspective. Detailed discussions on constitutional law are, hence, beyond the scope of our study, as are broader qualitative and quantitative inquiries on implementation, perceptions, policies, etc.

The work is organised in five parts. The first part (chapter 2) concerns human dignity of children, giving the ideological background of recognising children as autonomous and independent rights-holders, and functions as a backdrop for the rest of the contributions. It explores the tensions between autonomy and vulnerability and their implications for children's rights. The text is not tied to a specific country, although the author draws primarily on examples from Norwegian law.

The next parts analyse children's constitutional rights in specific Nordic countries. The chapters cover four topics: a general discussion on children's constitutional rights, the best interests-principle, participatory rights and the right to family life. Each contribution addresses one of the topics from the perspective of a single country. The contributions within each category do not follow a standard format - these are not national reports (Länderberichte), rather they reflect both core common issues and topical questions in each country. Because giving a full analysis of each country is beyond the scope of this book, each author has had discretion to select the most pertinent issues and examples from her perspective. Thus, the contributions also reflect the research interests of each author, and as all countries are small-to-medium size, oftentimes they also reflect the research done in each country. We believe this structure balances the need for coherence and comparability with the possibility to explore topics that are relevant and emerging in each of the countries studied. 
Chapters $3^{-7}$ discuss children's constitutional rights, in general, in each of the five Nordic countries. Each chapter explains the rights enshrined in the Constitution and implementation and enforcement of those rights. Because the CRC and a few other human rights covenants, most notably the ECHR, have a semi- or quasi-constitutional status in several of the Nordic countries, the status of the CRC is also covered to some extent. The variation in the degree to which Nordic Constitutions enshrine children's rights is mirrored in the content and depth of analysis in each chapter.

Chapters 8-10 investigate how the principle of the best interests of the child is recognised in each country studied, chapters $11-15$ discuss participatory rights, and chapters 16-19 family life.

The principle of the best interests is interesting both due to its pivotal role and due to its open character. While most, if not all, agree that the best interests of the child should be a primary consideration, the indeterminate character risks rendering it void of substantive content: it could be used to justify almost any outcome. ${ }^{34}$ The question is how the principle is interpreted in the Nordic countries and whether there any differences among the countries and different domains. What is the current definition(s) and how has the definition(s) changed over time?

The right to participation in decision-making is vital for exercising selfdetermination and the hallmark of an autonomous individual. However, patriarchal attitudes emphasising the need to protect children and provide care often bar children from participation. In effect, there seems to be a perceived contrariety between participation and the best interests of the child. From the perspective of children's rights, no such opposition exists. On the contrary, participation and best interests oftentimes dovetail, and even augment, each other. ${ }^{35}$ Again, the contributions explore the incongruences and lacunae in national constitutional protection and the implementation of these rights, both for collective and individual participation rights.

The right to family life is central for children in numerous contexts. Despite proliferation of alternative forms of family, new forms of reproduction and altering societal patterns, the concept of family is still based on idea of monogamous heterosexual couple and their biological children. A key question is how the right to family life is understood in the Nordic countries, and whether the understanding varies from one country and context to another.

34 Eg Robert van Krieken, 'The Best Interests of the Child and Parental Separation: On the Civilizing of Parents' (2005) 65(1) Modern Law Review 25-48, describes it as a 'black hole'.

Eg Freeman (n 3) p. 14. 
An exploration of the right to family life reveals the tension between traditional views of children as their parent's 'property' and views of children as autonomous individuals.

The three specific rights were chosen because two of them reflect two of the four general principles in the $\mathrm{CRC}$ as recognised by the Committee on the Rights of the Child (CRC Committee): ${ }^{36}$ the best interests-principle (article 3) and participation (article 12). The general principles in CRC article 6 enshrining the right to survival and development of the child are oftentimes not considered problematic in the Nordic countries. ${ }^{37}$ The principle of non-discrimination (CRC article 2) was excluded both because analysing children's rights illustrates the ways and the extent to which children are discriminated against vis-à-vis adults and because discussing vulnerable children, in particular, would have necessitated a far more voluminous study. Furthermore, rights primarily aiming at provision are not included in this study, because education and health care is universally available free-of-charge or at a very low cost in all Nordic countries, and social benefits for children and their families are also abundant. The right to family life was chosen because it is a pivotal right and it is enshrined in section 104 of the Norwegian Constitution, which is the Nordic Constitution with the widest coverage of children's rights.

The chapters within the four thematic groups are arranged according to the extent and manner of formal constitutional protection. Thus, Norwegian law is presented first followed by Finland, Iceland, Sweden and finally Denmark.

Children's constitutional rights are compared and contrasted in chapter 20 with regard to the question of whether and how enshrining children's rights in the Constitution is entangled with implementation and enforcement of those rights.

Studying children's rights in Nordic constitutional law serves additionally to exemplify some of the current issues and debates on children's rights in the

36 Committee on the Rights of the Child, General comment no. 5 (2003), general measures of implementation of the Convention on the Rights of the Child (27 November 2003) CRC/GC/ $2003 / 5$ at para 12 .

37 In its concluding observations on the periodic reports of the Nordic countries CRC Committee expresses no concern and recommendations in relation to article 6, except for the comments on Sweden, where suicide prevention is mentioned. See Committee on the Rights of the Child, Concluding observations Norway CRC/C/NOR/CO/5-6, 1 June 2018; Concluding observations Denmark CRC/C/DNK/CO/5, 26 October 2017; Concluding observations Sweden CRC/C/SWE/CO/5, 6 March 2015 Part B para 21-22 (suicide is mentioned), Concluding observations Iceland $\mathrm{CRC} / \mathrm{C} / \mathrm{ISL} / \mathrm{CO} / 3_{-4}, 23$ January 2012; Concluding observations Finland CRC/C/FIN/C/4, 3 August 2011. 
Nordic countries. These debates, inter alia, on balancing autonomy and protection, may help to unveil current trends in legislation, policy and research.

\section{References}

Andersen TM and others, The Nordic Model: Embracing globalization and sharing risks (The Research Institute of the Finnish Economy 2007).

Committee on the Rights of the Child, General comment no. 5, general measure of implementation of the Convention on the Rights of the Child (arts. 4, 42 and 44, para. 6) (27 November 2003) CRC/GC/2003/527.

Esping-Andersen G, The Three Worlds of Welfare Capitalism (Polity Press 199o).

European Commission for Democracy through Law (Venice Commission), Report on the Protection of Children's Rights: International Standards and Domestic Constitutions (3 April 2014) Opinion no 713 / 2013. CDL-AD (2014) o05.

Freeman M, 'Why it remains important to take children's rights seriously' (2007) 15 International Journal of Children's Rights 5-23 doi:10.1163/o927556o7X181711.

Friðriksdóttir H, 'Nordic family law: new framework-new fatherhoods', in GB Eydal, T Rostgaard (eds), Fatherhood in the Nordic Welfare States: Comparing Care Policies and Practice (Policy Press 2016).53-78.

Gilbert N, Combatting Child Abuse: International Perspectives and Trends (OU P 1997).

Helgadóttir R, 'Nonproblematic Judicial Review: A case study' (2011) 9 International Journal of Constitutional Law 532-547. doi: 10.1093/icon/moro55.

Hirschl R, 'The Nordic Counternarrative: Democracy, Human Development, and Judicial Review' (2011) 9 International Journal of Constitutional Law 446-469.

Husa J, 'Constitutional Mentality' in Letto-Vanamo P, Tamm D and Mortensen BOG (eds), Nordic Law in European Context (Springer 2019) 41-6o.

Husa J, 'Nordic Constitutionalism and European Human Rights: Mixing Oil and Water?' (2010) 55 Scandinavian Studies in Law 101.

Husa J, Nordic Reflection on Constitutional Law: A Comparative Nordic Study (Peter Lang 2002).

Husa J, 'Guarding the constitutionality of laws in the Nordic countries: A comparative perspective' (2000) 48 AmJCompL 345 .

Husa J, Nuotio K and Pihlajamäki H, 'Nordic Law: Between Tradition and Dynamism' in Husa J, Nuotio K and Pihlajamäki H (eds), Nordic Law: Between Tradition and Dynamism (Intersentia 2007).

Kjær AL, 'European Legal Concepts in Scandinavian Law and Language' (2011) 80 Nordic Journal of Human Rights 321.

Kronborg A, 'Family Formation in Scandinavia: A Comparative Study in Family Law' (2016) 12(2) Utrecht Law Review 81-93. 
Lavapuro J, Ojanen T and Scheinin M, 'Rights-Based Constitutionalism in Finland and the Development of Pluralist Constitutional Review' (2011) 9 International Journal of Constitutional Law 505-531, doi: 10.1093/icon/moro35.

Letto-Vanamo P and Tamm D, 'Nordic Legal Mind', in Letto-Vanamo P, Tamm D and Mortensen BOG (eds) Nordic Law in European Context (Springer 2019) 1-19.

Letto-Vanamo P and Tamm D, 'Cooperation in the Field of Law' in Strang J (ed), Nordic Cooperation: A European Region in Transition (Routledge 2015).

Lund-Andersen I and Kronborg A, 'Marriage and Family Relations', in Letto-Vanamo P, Tamm D and Mortensen BOG (eds), Nordic Law in European Context (Springer 2019) 97-113.

Nergelius J, 'Judicial Review in Swedish Law: A critical analysis' (2009) 27 Nordic Journal of Human Rights 142-159.

Nolan A, Children's Socio-Economic Rights, Democracy and the Courts (Hart Publishing 2011).

Nylund A, 'Family Maintenance and Multi-Speed Integration: A Norwegian Perspective' in Nylund A and Strandberg M (eds), Civil Procedure and Harmonisation of Law (Intersentia 2019) 209-230, in particular, 226.

Nylund A and Sunde JØ, 'Courts and Court Proceedings' in Letto-Vanamo P, Tamm D and Mortensen BOG (eds), Nordic Law in European Context (Springer 2019) 201-213.

Ojanen T, 'From Constitutional Periphery Toward the Centre: Transformation of Judicial Review in Finland' (2009) 27 Nordic Journal of Human Rights 194-207.

O’Mahony C, 'Constitutional Protection of Children's Rights: Visibility, Agency and Enforceability' (2019) 19 Human Rights Law Review (in press).

Petersen JH, 'Nordic Model of Welfare States' in Letto-Vanamo P, Tamm D and Mortensen BOG (eds) Nordic Law in European Context (Springer 2019) 21-39.

Pösö, T, Skivenes M and Hestbæk AD, 'Child Protection Systems Within the Danish, Finnish and Norwegian Welfare States: Time for a Child Centric Approach?' (2014) 17 Eur J of Social Work 475.

Reynaert D and others, 'Introdcution: A critical approach to Children's Rights' in Vandenhole W and others (eds), Routledge International Handbook of Children's Rights Studies (Routledge 2015).

Rytter, JE, and Wind M, 'In Need of Juristocracy? The Silence of Denmark in the Development of European Legal Norms' (2011) 9 International Journal of Constitutional Law 470-504, doi: 10.1093/icon/moro39.

Sand, IJ, 'Judicial Review in Norway under Recent Conditions of European Law and International Human Rights Law: A Comment' (2009) 27 Nordic Journal of Human Rights 16o-169.

Schaumburg-Müller S, 'Parliamentary Precedence in Denmark: A Jurisprudential Assessment' (2009) 27 Nordic Journal of Human Rights 170-184. 
Sloth-Nielsen J and Kruuse H, 'A Maturing Manifesto: The Constitutionalisation of Children's Rights in South African Jurisprudence 2007-2012' (2013) 21 International Journal of Children's Rights 646.

Smith E, 'Old and Protected? On the "Supra-Constitutional" Clause in the Constitution of Norway' (2011) 44 Israel Law Review 369-388.

Smith E, 'Courts and Parliament: The Norwegian System of Judicial Review of Legislation' in Eivind Smith (ed), The Constitution as an Instrument of Change (sNs Förlag 2003) 171.

Tobin J, 'Increasingly Seen and Heard: The Constitutional Recognition of Children's Rights' (2005) 21 South African Journal on Human Rights 86-126.

Vandenhole W, 'Children's rights from a legal perspective: Children's rights law' in Vandenhole W and others (eds), Routledge International Handbook of Children's Rights Studies (Routledge 2015).

Van Krieken R, 'The Best Interests of the Child and Parental Separation: on the Civilizing of Parents' (2005) 65(1) Modern Law Review 25-48.

Warner-Søderholm G, 'But We're Not All Vikings! Intercultural Identity within a Nordic Context' (2012) 29 J of Intercultural Communication. 